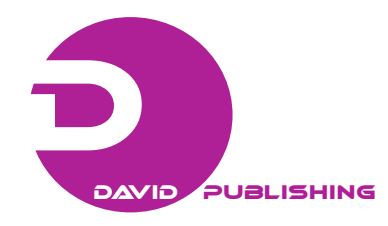

\title{
Pain and “Mourning” in Poe’s Tales
}

\author{
Margarita Rigal Aragón \\ Universidad de Castilla-La Mancha, Spain
}

\author{
Ricardo Marín Ruiz \\ Universidad de Castilla-La Mancha, Spain
}

\begin{abstract}
The purpose of this essay is to deepen into an aspect which has often been neglected by Spanish Poe. Researchers usually concentrate on the analysis of how the American writer treats death, and, above all, the death of a beautiful woman; however, hardly ever it is studied other funeral casuistry of this literary genius (the death of a young man, the afterlife, the demystification of the terrifying vision of death by making use of humour, etc.). The "mourning” process that Poe characters and narrators undergo when faced up to their own deaths or those of their beloved people is focused here (among other death-related experiences), demonstrating that Poe's tales contain much more than the gothic recreation of the death of a beautiful lady.
\end{abstract}

Keywords: pain, mourning, Poe, tales, death

\section{Sufrimiento y “duelo" en los relatos de Poe}

El propósito de este artículo es profundizar en un aspecto que los especialistas españoles en Poe a menudo han ignorado; éstos se dedican por lo general a analizar la forma en la que el escritor norteamericano trata la muerte-especialmente, la muerte de una bella mujer; sin embargo, casi nunca se ha abordado la casuística funeraria de este genio literario (el fallecimiento de un joven, la vida después de la muerte, la desmitificación de la terrible visión de la muerte haciendo uso del humor, etc.). Por ello, se estudia aquí, de manera especial, el dolor que experimentan los personajes y los narradores de Poe cuando se enfrentan a sus propias muertes o las de sus seres queridos, demostrando así que sus relatos versan sobre mucho más que la mera recreación gótica del fallecimiento de una bella mujer.

Palabras clave: sufrimiento, duelo, Poe, relatos, muerte

\section{Pain and "Mourning” in Poe's Tales}

"Do you still feel pain in the breast, M. Valdemar?” [...]

"No pain — I am dying.” [...]

"M. Valdemar, can you explain to us what are your feelings or wishes now?”

There was an instant return of the hectic circles on the cheeks; the tongue quivered, or rather rolled violently in the mouth (although the jaws and lips remained rigid as before and at length the same hideous voice which I have already described, broke force:

"For God's sake! — quick! — quick! — put me to sleep — or, quick! Waken me! — quick! — I say to you that I am dead!

Margarita Rigal Aragón,professor,Universidad de Castilla-La Mancha.

Ricardo Marín Ruiz, professor ,Universidad de Castilla-La Mancha.

Correspondence concerning this article should be addressed to Universidad de Castilla-La Manch. E-mails: Margarita.Rigal@uclm.es; Ricardo.Marin@uclm.es. 


\section{Introduction}

Readers from the Romantic period shuddered with pleasure at the sight of open tombs along with further facing of death, a topic which powerfully drew the attention of the literature and paintings of that moment. As it has been argued, no other writers from that time knew how to convey the idea of death shared by his contemporaries better than Poe. In an expanding America, the new and prosperous middle — class frowned at the common grave; tombs, tombstones and mausoleums turned into symbols of the progress of democracy, especially in the south, where it was of paramount importance to be buried as a gentleman or lady. In a period when women were buried with their wedding dresses on, the image of the beautiful and young deceased woman was supposed to be the greatest exponent of love beyond death, a circumstance which unveils a relationship between the surrender to sexual instincts and death.

As well known, death, in its different versions, emerges throughout the great part of Poe's literary production. From "Metzengerstein" (1832) to "Mellonta Tauta” and "Hop-Frog” (both from 1849), death reveals itself as one of the main topics; the same applies to a great deal of Poe's poetry, swelled with an elegiac tone. Some scholars complain the persistent tendency to attribute Poe's obsession for death to a morbid sensitiveness, a neurosis rooted in his childhood, a conscious exploitation of the conventions of the gothic genre, or an esoteric symbolism to explain philosophical or aesthetic aspects. (Edward H. Davidson, 1969) Similarly, Robert Giddings (1990) insists on how fascinated Poe was about not death itself, but its rituals, underlining as main themes the ceremonious treatment of death, the mistaking of the epileptic state for the real death, and the dialogue between the living and the deceased. It is worth mentioning the fact that they can only find throughout the whole "gothic" production of the author of "The Raven" two narratives in which no character passes away: "The Elk" and "Landor's Cottage". The part of his narrative production labeled as "grotesque" contains high doses of the topic as well, sometimes under an ironic perspective though.

Poe researchers have often concentrated on the analysis of how he treated death, and, above all, the death of a beautiful woman. However, not often it is studied other funeral casuistic of this literary genius (like the death of a young man — most of the times bound to a lady's decease — the afterlife, the demystification of the terrifying vision of death by making use of humor, etc.). There is an aspect which has been neglected even with more frequency: Can the process through which many of Poe's characters go as they die, be considered painful or not? That is to say, how do those characters face up to their own deaths or those of their beloved people?

According to Kennedy (2001), Poe's period was that of "the Beautiful Death", a time when death turned into a fetishist spectacle, in a meticulously elaborated farewell, where the deathbed became a place of beatific privacy and the corpse was an object of idolatry and commemoration. This being so, the craft of mourning before the deceased thrived during the $19^{\text {th }}$ century thanks to a complete iconography which made the melancholy around death increase. This impulse had its main exponent in the death of the beloved woman, a young and beautiful woman, whose leaving symbolized the permanence of an innocence which she would have lost in case she had continued to be alive. In "The Philosophy of Composition”, Poe (1984) would maintain that the death of a beautiful woman was, undoubtedly, the most poetic topic in the world (p. 19). As it has been stated many times, this topic is the central theme of "Morella" (1835), "Berenice” (1835), "Ligeia” (1838), "The Fall of the House of Usher” (1839), “Eleonora” (1841), and "The Oval Portrait” (1842). In six of them, the narrator tells the facts under the effects of opium, terror, or dementia; as a result, the reader must decide to stick to the words uttered by the narrator or regard them either as the vision of a deformed mind or as 
manifestation of a popular belief according to which those who are under the influence of drugs see what the rest of people cannot. However, it is not usually stressed the fact that although the topic they all deal with is the death of a dainty woman who has hardly gone through the threshold of adolescence, that female character is not the main character, but the man who had fallen under her influence. As it is well known, in these tales the gothic atmosphere is impressive: Chambers full of books and ottomans, closed spaces, castles, abbeys, etc., are the settings of these narrations which are at the same time true love and/or hatred stories. The relationships held by the couples appearing throughout these tales are controvert and always leading to the decease of the female character. The affection Morella's husband feels for her, turns suddenly into a different sentiment, and this to such an extent that he desperately desires her death. Certainly, the association between the Usher brothers is curious: He craves for Madelaine's death so much that he buries her alive, but neither of them can live without the other. The strange relationship between Berenice and Egaeus, sprinkled with contrasts, is similar in the sense that Berenice falls seriously ill and dies just when their marriage was being planned. In "Ligeia", the narrator is madly in love with a young lady, but death takes her away from him and when he gets married for the second time, he looks forward to the decease of his new wife. The only story that love surmounts everything is "Eleonora". In all of them, the characters undergo intense emotional pain while being confronted with their own death or that of their dear-ones. The masterly description of the pain reflected on the countenance of the young Usher will serve as an example:

A cadaverousness of complexion; an eye large, liquid and luminous beyond comparison; lips somewhat thin and very pallid...The now ghastly pallor of the skin, and the now miraculous lustre of the eye, above all things startled and even awed me. The silken hair, too, had been suffered to grow all unheeded, and as, in its wild gossamer texture, it floated rather than fell about the face, I could not, even with effort, connect its Arabesque expression with any idea of simple humanity... To an anomalous species of terror I found him a bounden salve. "I shall perish", said he, "I must perish in this deplorable folly. Thus, thus, and not otherwise, shall I be lost. I dread the events of the future, not in themselves, but in their results. I shudder at the thought of any, even the most trivial, incident, which may operate upon this intolerable agitation of soul. I have, indeed, no abhorrence of danger, except in its absolute effect — in terror. In this unnerved — in this pitiable condition - I feel that the period will sooner or later arrive when I must abandon life and reason together, in some struggle with the grim phantasm, FEAR” (pp. 401-2).

However, as above pointed out, in this essay they want to concentrate on other less studied cases of Poe's mourning characters: Despite not being traditionally included among those stories in which the death of a young lady occurs, narrations such as "The Assignation” (1834), "The Murders in the Rue Morgue” (1841), "The Mystery of Marie Roget” (1842-43), "The Oblong Box" (1844), the comic stories "The Thousand—and—Second Tale of Scheherazade” (1845), “A Predicament” (1838) and "Mellonta Tauta” (1849) should also be taken into account when dealing with the topic of painful and painless women's deceases.

\section{Pain, Suffering, and the Death of “Other” Females}

"The Assignation" is the first prose love story by Poe; though in this case the decease of the young lover is more important, this would not have occurred if it had not been for the existence on an impossible love, and for the necessity for the young woman to die as the only way to get rid of her husband. The underlying idea throughout the story, which they can learn by means of the inserted poem, is that the lovers will not be able to meet each other until they die: "Thou wast that all to me, love, / For which my soul did pine [italics ours]"(pp. 161-2). As it is customary in Poe's style, the narration is spattered with notes foretelling a tragic and painful ending: the fall of the child into the canal (a death omen), the black marble, the unsteadiness of the figure of the 
young woman, etc.

“The Oblong Box" also includes an intense love story; Mr. Wyatt, the narrator's acquaintance travels in a ship with a strange box which, curiously enough, is not kept in the hold, but in his cabin. Every night, the narrator hears Mr Wyatt open up the box and moan in pain. The secret kept is the death of the young and beautiful Mrs. Wyatt, who had died a few days before the ship set out; the artist, madly in love with her and sick because of her loss, does not want anything but to take hold of the body of his spouse and never be away from it. In consequence, the reader is presented with another case of a male suffering from the terrible ache of the death of his be - loved. Later on, when confronted with the sinking of the ship in which they were travelling, and seeing that he was not allowed to take the box with him, he completely lost control of himself and succumbed to suicide.

Also, in two of Poe's "detective” stories they witness the decease of a young female; however, in these cases the victim does not correspond to a woman loved by the narrator: "The Murders in the Rue Morgue” and “The Mystery of Marie Rogêt”. Marie Rogêt is clearly told to be beautiful, and Madame L'Espanye's daughter's youth is stressed. They can see here that the topic of death is developed in a totally different tenor to the above analysed tales. The human aspect is pushed into the background in the interests of the scientific meticulousness, of the study of clues. In spite of that, the figure of Marie (in the second of the stories) is much more elaborated, perhaps because of the fact that Poe is describing a real murder and is conscious that the attention of more readers (like, for example, relatives and friends) may be easily drawn by going into detail in the human and sentimental side of the victim. They know that these three women must have suffered from intense pain, however they do not feel that pain as they feel that of Roderick, or Ligeia's husband, because their hearts are not made to convulse together with theirs. In "Murders" they are told about a "succession of terrific shrieks" (p. 537); they are also given the description of the apartment, which was "in the wildest disorder — the furniture broken and thrown about in all directions...On a chair lay a razor, besmeared with blood” (p. 537). The newspapers continue their story with the account, which is "horrible to relate" (p. 538), of the finding of Mademoiselle's corpse inside the fire — place:

... head downward, was dragged there - from; it having been thus forced up the narrow aperture for a considerable distance ...many excoriations were perceived, no doubt occasioned by the violence with which it had been thrust up and disengaged. Upon the face were many severe scratches, and, upon the throat, dark bruises, and deep indentations of finger nails, as if the deceased had been throttled to death (p. 538).

The luck of the mother had not been better as her body was found laying on a small yard, "With her throat so entirely cut that, upon an attempt to raise her, the head fell off” (p. 538). Marie Rogêt's death was also atrocious: "The face was suffused with dark blood, some of which issued from the mouth...About the throat were bruises and impressions of fingers. The arms bent over on the chest. The right hand was clenched...” (p. 730).

Poe's "grotesque” production also provides examples in which the death of a (probably) young and (probably) beautiful woman takes place, though critics have not heeded this aspect. Thus, in "The Thousand-and-Second Tale of Scheherazade”, Scheherazade volunteered to get married with a caliph who had already killed a high number of wives, whom he ordered to be murdered the morning after the wedding night, to avenge the treason committed by his first spouse. Scheherazade is convinced that she has a perfect plan to dodge that atrocious fate. However, her contrivance does not succeed as the caliph is not interested in one of 
her stories any longer, what leads him to decide that it is time to kill her. In this case, however, the death of the beautiful young lady is almost deprived of pain, which is seen as something natural, frivolous, and even fun, for as her husband announces her that she shall be throttled, she was "grieved" and "astonished", but "she submitted to her fate with a good grace” (p. 70). In “A Predicament” (1838), people are again confronted with the death of a woman (whose age, beautifulness or ugliness they are not reported). After having followed the advice she received from the editor of the Blackwood of writing an essay or tale providing examples of extravagant and/or exaggerated deaths, Signora Psyche Zenobia (together with her servant and an aiding dog) suffers from several "grotesque" deceases, which she accounts for in her article. Pundita, in "Mellonta Tauta" (1849), may be regarded as another example of a dead young woman, who seems to fall into death when the mechanism of the balloon in which she travels breaks down. She shows no alarm, no suffering, nor fear at all:

"But Heaven bless me! What is the matter? Ah, I see — the balloon has collapsed, and we shall have a tumble into the sea...Good bye, until I see you again. Whether you ever get this letter or not is appoint of little importance, as I write altogether for my own amusement. I shall cork the MS. up in a bottle, however...” (p. 1305).

In these tales, together with "Loss of Breath" (1832, later discussed), people, as readers, are drawn against cartoonish stories, in which the characters suffer several deaths as they continue to tell people their adventures. As Scott Peeples (2010) has argued, it is no wonder people do not feel sorry for them, neither is there any sensation of pain transmitted to them (p. 37).

\section{Pain, Suffering, and the Death of Young Males}

People pointed out above that most critics have found in the topic of the deceased young female one of the capital points of Poe's works; nevertheless, there is another relevant topic which is usually forgotten: the death of a young man not linked to a lady's death, a deed leading also to an intense spiritual pain. It happens thus in the first of Poe's "gothic" stories, "Metzengerstein", where the decease of a man being in the prime of his life is described by the author with great dramatic intensity. After having lost his parents, one night, the young count Metzengerstein sees - "to his extreme horror and astonishment" (p. 22) — how a weird horse gets out of a tapestry he was staring at; that night, his rival Berlifitzing dies and, short time after, Metzengerstein himself dies as he is overcome with panic when riding the horse as which his neighbour had reincarnated: "The agony of his countenance, the convulsive struggle of his frame, gave evidence of superhuman exertion: But no sound, save a solitary shriek, escaped from his lacerated lips, which were bitten through and through the intensity of terror” (p. 29).

Further examples of the torment experienced by young men when they are about to cross the border between life and death can be traced among the gothic tales. For example, William Wilson (1839), on the point of passing away, reflects: "And I am not now dying a victim to the horror and the mystery of the wildest of all sublunary visions” (p. 427). Also, in A Descent into the Maelström, the brother succumbing in the middle of the storm narrates:

"As we approached the brink of the pit he let go his hold upon this and made for the ring, from which, in the agony of his terror, he endeavoured to force my hands [...] I knew he was a madman when he did it - a raving maniac through sheer fright” (p. 584).

But despite having died, he seems not to have been more fortunate than that who survives:

“...about three years past, there happened to me an event such as never happened to mortal man — or at least no man 
ever survived to tell off — and the six hours of deadly terror which I then endured have broken me up body and soul” (p. 577).

Again, in "The Masque of the Red Death", Prince Prospero — presumably young — used to live "happy and dauntless and sagacious” (p. 670). But he, as well as his courtiers, cannot escape from a terrifying death when the plague approached them: "And now was acknowledged the presence of the Red Death...And one by one dropped the revellers in the blood - bedewed halls of their revel, and died each in the despairing posture of his fall” (pp. 676-77).

Young or not, the male protagonists of quite a few of Poe's "grotesques" also find their deaths along the narrations. In these tales, death is disdramatized, in the sense that it is considered as a matter of scarce importance, pain being never mentioned or seemed to be experienced by the characters. Thus, for instance, in "The Duc de l'Omelette" (1832), a duke dies when he chokes on an olive and stakes his entry to Hell playing cards with the Devil himself. Similar tone and theme can be found in "Bon-Bon" (1832); on this occasion, the restaurateur is defeated by the Devil when risking his life in a card game, however, the latter spares his life as he does not want to take advantage of a drunken man. In "Never Bet the Devil your Head"(1841), the main character, Toby Dammit, perishes victim of his rash tendency to bet the Devil his head, however, in the end the narrator explains how his head was still alive for a few days after being separated from the body. "A Premature Burial" presents people with a case in which the narrator dreams to have been buried alive; eventually, he wakes from this horrific nightmare and sets himself free from his fears. In "Some Words with a Mummy" (1845), the story of a mummy, brought back to life by means of the new medical techniques, the narrator after having heard of the trend at that time to be embalmed and, given the appropriate instructions, awoken many years later decides to undergo the same process and to be awoken in the year 2045 in order to witness the changes occurred in the world. A key narration within this comic and satirical line is one of Poe's first cartoon — like stories, "Loss of Breath" where the narrator endures many atrocities and dies several deaths (he is first suffocated, then his skull is fractured, several of his viscera are removed, then he is hanged and, finally, he is buried "alive"); all of these, without experiencing much pain, for the only time he complains when part of his nose was about to be cut off, "burning with indignation" (p. 68).

\section{Pain, Suffering, and the Victims of Murder (or Imminent Death)}

Three of Poe's most discussed non—detective stories are The Tell—Tale Heart” (1842), "The Black Cat" (1843) and "The Cask of Amontillado" (1846), along with "The Imp of the Perverse" (1845), "William Wilson" (already mentioned), "Thou Art the Man” (1844) and "Hop-Frog” (seen later) — narrate murders. Nevertheless, little if no attention at all is paid to the suffering of the victims. For instance, in "Thou Art the Man" and in "The Imp" no mention whatsoever is made of the pain perpetrated by the assassins upon their targets. The protagonist's wife in "The Black Cat" was "uncomplaining...and the most patient of sufferers" (p. 856); she dies, when she tries to stop her husband from killing their new cat, uttering no word: "I withdrew my arm from her grasp and buried the axe in her brain. She fell dead upon the spot, without a groan” (p. 856). For his part, Montresor ("The Cask") thinks that he is being ushered to a far and deep vault to taste a wonderful wine; when he discovers that he is being walled, he cannot resume himself to believe it, exclaiming: "Ha! ha! ha! — he! he! — a very good joke indeed...” (p. 1263). The old man's intervention in "The Tell-Tale" is dispatched with a single sentence: "Who's there?” (p. 793) however, his suffering is well described by his killer, for an hour he was still, "harkening to death watches in the wall", referencia and then: "Presently I heard a 
slight groan, and I knew it was the groan of mortal terror. It was not a groan of pain or of grief — oh, no! — it was the low stifled sound that arises from the bottom of the soul when overcharged with awe".

If the sufferings of these victims are almost (or totally) unuttered, the mental wanderings of the murders are made quite clear to readers. One of the best but least analysed among the several and detailed descriptions of the internal pain underwent by Poe's criminals can be found in "The Imp of the Perverse":

We stand upon the brink of a precipice. We peer into the abyss -we grow sick and dizzy [...] By slow degrees our sickness, and dizziness, and horror, become merged in a cloud of unnameable feeling [...] Examine these and similar actions as we will, we shall find them resulting solely from the spirit of the Perverse. We perpetrate them merely because we feel that we should not. Beyond or behind this, there is no intelligible principle.

The same clarity and depth of emotions is displayed by Poe in his well-known "MS. Found in a Bottle" (1833) and "The Pit and the Pendulum" (1842). In both of them the narrators explain their apprehensions as they approach the end of their lives (or what might have been the end of them). On board of a ship, travelling towards the Archipelago of the Sunda Islands, the main character of "MS", and after having observed "a very singular, isolated cloud” (p. 136) felt a "full presentiment of evil” (p. 136). From then on: “All around were horror, and a thick gloom, and a black sweltering desert of ebony" (p. 139). When some days had passed, the main character "beheld a spectacle which froze the current of [his] blood" (p. 140) as a huge ship approximated them. Having now lost his ship and his only companion, he ended up on board of this strange vessel which was inhabited by a peculiar crew of living - dead who never saw him. In this context, as the narrator is about to "penetrate the mysteries" of those awful regions, he feels that to "conceive the horror of [his] sensations is [...] utterly impossible” (p. 145).

Although the protagonist does not find death at the end of the story, "The Pit" is clearly bounded to the fear experienced by a person when he/she knows that a terrible end is expecting them. Scott Peeples has argued that if there is a story by Poe which is definitely about pain, it is "The Pit". The feelings of the narrator, when sentenced to death, are so intense that: "there stole into [his] fancy, like a rich musical note, the thought of what sweet rest there must be in the grave...”And then:“the blackness of darkness supervened; all sensations appeared swallowed up in a mad rushing descent. Then silence, and stillness, and night were the universe” (p. 682). His panic increases, he wonders which type of execution had the judges chosen for him; and like the narrator of "The Tell-Tale" - he sensed "the tumultuous motion of the heart, and, in my ears, the sound of its beating” (p. 683). Throughout the whole narrative, Poe succeeds in transmitting the reader the horror of the condemned to death, while speculating about his fate

Having begun this essay with a quotation from "The Facts in the Case of M. Valdemar" (1845), they would like to reflect on this, and on "Hop-Frog”, however different they may be (or seem to be). "Hop-Frog" has always been regarded as a grotesque due to its light tone:

"Dwarfs were as common at court, in those days, as fools; and many monarchs would have found it difficult to get through their days (days are rather longer at court than elsewhere) without both a jester to laugh with, and a dwarf to laugh at” (p. 1345).

In spite of this tone, this is one of Poe's bitterest tales on revenge and murder. Having been abused by the King — as Montresor had been by Fortunato, Hope-Frog plans a quick vendetta on the person of his majesty and his seven ministries. Like in the other murder tales, the pain of the victims while being burned is not reported, but they do get a clear image of the moral offence perpetrated upon the person of Hop — Frog (when 
being made to drink to illness) and of the physical — and moral — offence Trippetta received when she tried to help her friend:"Trippetta, pale as a corpse, advanced to the monarch's seat, and falling on her knees before him, implored him to spare her friend. He pushed her violently from him, and threw the contents of the brimming goblet on her face. The poor girl got up as best as she could, and, not daring to sigh, resumed her position at the foot of the table” (pp. 1348-49).

Whether intended or not as a hoax, "The Facts" shows the anguish of someone who is passing away. Like Mr. Vankirk, in "Mesmeric Revelation” (1844), M. Ernest Valdemar endures a real physical pain. Vankirk suffered from an "acute pain on the region of the heart, and breathed with great difficulty" (p. 1030) on his part, Valdemar, was affected with a disease of "that character which would admit of exact calculation in respect to the epoch of its termination in death" (p. 1234). His lungs were "partially, if not thoroughly, ossified" (1235) and he had a great ache on his breast: "The lower region [of his right lung] was merely a mass of purulent tubercles". Both men agreed to be mesmerized in articulo mortis; in "Mesmeric Revelation" Poe focuses on the transcendental experience of demise: "There are two bodies — the rudimental and the complete; corresponding with the two conditions of the worm and the butterfly. What they call "death" is but the painful metamorphosis. Our present incarnation is progressive, preparatory and temporary. Our future is perfected, ultimate and immortal. The ultimate life is the full design. Meanwhile, in "The Facts", the emphasis is put onto the struggle between the soul and the body (to let it go) and the physical effects of "artificially" delaying death: "As I rapidly made the mesmeric passes, amid ejaculations of "dead! dead!" absolutely bursting from the tongue and not from the lips of the sufferer, his whole frame at once - within the space of a single minute, or even less, shrunk-crumbled rotted away beneath my hands. Upon the bed, before that whole company, there lay a nearly liquid mass of loathsome - of detestable putridity" (pp. 1242-43). This Poe's most gruesome description of death is similar to the one underwent by the King and his ministries in "Hop-Frog": "The eight corpses swung in their chains, a fetid, blackened, hideous and indistinguishable mass" (p. 1354). Nevertheless, the reader can deduce that the putrefaction is due to the evilness of the souls of these eight characters, and not to the intervention of a scientific experiment (such being the case of Valdemar).

As they have extensively proved, pain and suffering are revisited once and again in Poe's funeral catalogue. Regardless of his stories being comic of not, regardless of them being serious Gothic or slapstick Gothic, regardless of the author's ultimate intention of mocking or not Gothicism, Poe transmits the reader the intensity of the terror which precedes death. Poe portrays almost to perfection (if not perfection itself), the anguish of the criminal, the fear of the tormented soul, the terror of terrors, because, he, like the judges of the Inquisition, knew that "There was a choice of death with its direst physical agonies, or death with its most hideous moral horrors" (p. 687). Probably because he also knew that he "had been reserved for the latter" (p. 687).

\section{References}

Davidson, Edward H. (1969). Poe: A Critical Study. Cambridge: Harvard University Press. Edgar Allan Poe. (1984). Essays and Reviews. (p. 19). New York: The Library of America.

Giddings, Robert. (1990). Poe: Rituals of Life and Death. Brian Docherty (Ed.), American Horror Fiction, Vol. IX. (pp. 33-58). New York: Palgrave Macmillan.

Kennedy, J. Gerald. (1987). Poe, Death and the Life of Writing. New Haven: Yale University Press.

Kennedy, J. Gerald. (2001). Introduction. J. Gerald Kennedy (Ed.), A Historical Guide to Edgar Allan Poe. (pp. 3-17). Oxford: Oxford University Press. 
Leverenz, David. (2001). Spanking the Master: Mind-Body Crossings in Poe’s Sensationalism. J. Gerald Kennedy (Ed.), A Historical Guide to Edgar Allan Poe. (pp. 95-128). Oxford: Oxford University Press.

Levine, Stuart., \& Levine, Susan. (1990). The Short Fiction of Edgar Allan Poe. Urbana and Chicago: University of Illinois Press. Peeples, Scott. (2010). “Poe and Pain.” Margarita Rigal—Aragón \& Beatriz González Moreno (Eds.), Edgar Allan Poe: Doscientos años después/ Two Hundreds Years Later. (pp. 37-47). Cuenca: Servicio de Publicaciones de la Universidad de Castilla-La Mancha.

Person, Leland S. (2001). "Poe and Nineteenth—Century Gender Constructions.” J. Gerald Kennedy (Ed.), A Historical Guide to Edgar Allan Poe. (pp. 120-166). Oxford: Oxford University Press. .

Poe, Edgar Allan. (1984). Essays and Reviews. New York: The Library of America.

Poe, Edgar Allan. (2000). Tales and Sketches. Thomas Ollive Mabbot (Ed.), Urbana and Chicago: University of Illinois Press.

Rigal-Aragón, Margarita. (1998). Aspectos estructurales y temáticos recurrentes en la narrativa breve de Edgar Allan Poe. Cuenca: Servicio de Publicaciones de la Universidad de Castilla—La Mancha. 